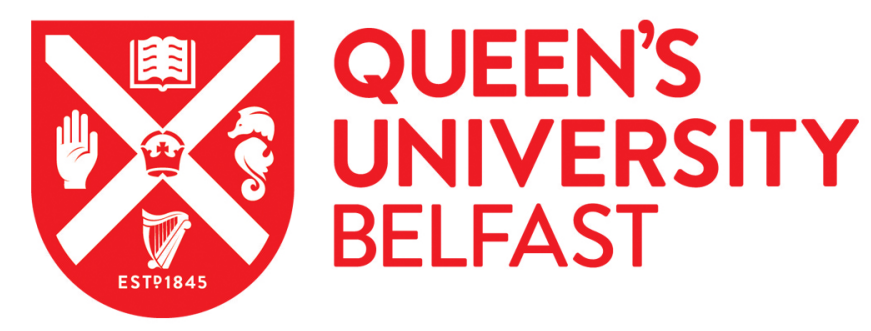

\title{
Restoration of glutathione levels in vascular smooth muscle cells exposed to high glucose conditions
}

Powell, L., McNally, S. M., McMaster, D., Catherwood, M. A., \& Trimble, E. (2001). Restoration of glutathione levels in vascular smooth muscle cells exposed to high glucose conditions. Free Radical Biology and Medicine, 31(10)(10), 1149-1155. https://doi.org/10.1016/S0891-5849(01)00648-7

Published in:

Free Radical Biology and Medicine

Queen's University Belfast - Research Portal:

Link to publication record in Queen's University Belfast Research Portal

\section{General rights}

Copyright for the publications made accessible via the Queen's University Belfast Research Portal is retained by the author(s) and / or other copyright owners and it is a condition of accessing these publications that users recognise and abide by the legal requirements associated with these rights.

Take down policy

The Research Portal is Queen's institutional repository that provides access to Queen's research output. Every effort has been made to ensure that content in the Research Portal does not infringe any person's rights, or applicable UK laws. If you discover content in the Research Portal that you believe breaches copyright or violates any law, please contact openaccess@qub.ac.uk. 


\title{
RESTORATION OF GLUTATHIONE LEVELS IN VASCULAR SMOOTH MUSCLE CELLS EXPOSED TO HIGH GLUCOSE CONDITIONS
}

\author{
Lesley A. Powell, ${ }^{\dagger}{ }^{\dagger}$ Sinead M. Nally, ${ }^{\dagger}$ Dorothy McMaster, ${ }^{*}$ Mark A. Catherwood,${ }^{\dagger}$ and \\ ELISABETH R. TRIMBLE** \\ *Department of Clinical Biochemistry, The Royal Group of Hospitals, Belfast, UK; ‘Department of Clinical Biochemistry, \\ Queen's University, Belfast, UK; and ${ }^{\star}$ Department of Medicine, Queen’s University, Belfast, UK
}

(Received 15 May 2001; Accepted 28 June 2001)

\begin{abstract}
Hyperglycemia-induced oxidative stress may play a key role in the pathogenesis of diabetic vascular disease. The purpose of this study was to determine the effects of glucose on levels of glutathione (a major intracellular antioxidant), the expression of $\gamma$-glutamylcysteine synthetase (the rate-limiting enzyme in glutathione de novo synthesis), and DNA damage in human vascular smooth muscle cells in vitro. High glucose conditions and buthionine sulphoximine, an inhibitor of $\gamma$-glutamylcysteine synthetase, reduced intracellular glutathione levels in vascular smooth muscle cells. This reduction was accompanied by a decrease in the mRNA expression of both subunits of $\gamma$-glutamylcysteine synthetase as well as an increase in DNA damage. In high glucose conditions, incubation of the vascular smooth muscle cells with $\alpha$-lipoic acid and L-cystine restored glutathione levels. We suggest that the decrease in GSH levels seen in high glucose conditions is mediated by the availability of cysteine (rate-limiting substrate in de novo glutathione synthesis) and the gene expression of the $\gamma$-glutamylcysteine synthetase enzyme. Glutathione depletion is associated with an increase in DNA damage, which can be reduced when glutathione levels are restored. () 2001 Elsevier Science Inc.
\end{abstract}

Keywords-High glucose, Glutathione, $\gamma$-Glutamylcysteine synthetase, DNA damage, Vascular smooth muscle cells, Cyst(e)ine, $\alpha$-Lipoic acid, Free radicals

\section{INTRODUCTION}

Vascular disease is responsible for most of the long-term complications of diabetes mellitus, and these changes are associated with hyperglycemia-induced oxidative stress. Glutathione (GSH), an important intracellular antioxidant, is depleted in erythrocytes [1], plasma [2], leucocytes [3], and platelets from human diabetic patients [4] and in endothelial cells from diabetic rabbits [5]. The changes in GSH levels, which result in an oxidant/prooxidant imbalance, may predispose the cells to oxidantinduced damage and diabetic complications.

GSH is the principal intracellular thiol and provides defense against oxidative stress by scavenging free radicals or causing the reduction of hydrogen peroxide. Under conditions of oxidative stress, GSH is oxidized to

Address correspondence to: Dr. Lesley A. Powell, Department of Clinical Biochemistry, Queen's University of Belfast, Institute of Clinical Science, Grosvenor Road, Belfast BT12 6BJ, UK; Tel: +44 2890 263018; Fax: +44 28 90236143; E-Mail: 1.powell@qub.ac.uk. glutathione disulphide (GSSG) by glutathione peroxidase (GPx); GSSG is then reduced to GSH by glutathione reductase through the coupling reaction of NADPH to NADP. Hence, GSH influences the redox status of the cell, which is critical for various biochemical functions including modulation of the activity of redox-sensitive transcription factors [6,7], transcription of specific genes, regulation of cell proliferation, and apoptosis [8].

GSH is synthesized from its constituent amino acids (glutamate, cysteine, and glycine) by the activity of two ATP-dependent enzymes, $\gamma$-glutamylcysteine synthetase $(\gamma$-GCS) and glutathione synthetase with $\gamma$-GCS, catalyzing the rate-limiting step of GSH synthesis [9]. Gamma-GCS is a heterodimer composed of a heavy $(73 \mathrm{kDa})$ and light $(29 \mathrm{kDa})$ subunit. The heavy subunit $\left(\gamma-\mathrm{GCS}_{\mathrm{H}}\right)$ exhibits catalytic activity and is subject to nonallosteric inhibition by GSH [10]. The light subunit $\left(\gamma-\mathrm{GCS}_{\mathrm{L}}\right)$ regulates the catalytic activity of the heavy subunit [11]. Two distinct genes encode the heavy and light subunits and marked tissue-specific expression of the subunits 
have been observed, which may contribute to tissuedependent regulation of enzymatic activity [12].

Several studies have demonstrated the reductions in gene expression of the heavy subunit of $\gamma$-GCS and activity of $\gamma$-GCS in high-glucose conditions [13-15]. However, regulation of $\gamma$-GCS activity at the mRNA level with respect to both the light and heavy subunits has not been investigated in high glucose conditions. In view of the importance of GSH in hyperglycemia-induced oxidative stress, the effects of high glucose on GSH synthesis, $\gamma$-GCS mRNA expression, and DNA damage were investigated in human vascular smooth muscle cells (HVSMC).

\section{EXPERIMENTAL PROCEDURES}

\section{Tissue culture materials and reagents}

All chemicals were obtained from Sigma Chemical Co. (St. Louis, MO, USA) unless otherwise stated. RPMI 1640, L-cystine, and fetal calf serum (FCS) were purchased from Life Technologies (Gaithersburg, MD, USA).

\section{Isolation and culture of HVSMC}

HVSMC were obtained from aortae of transplant donors after written consent was obtained from the relevant family member (the study was approved by the Ethical Committee of Queen's University of Belfast). Cells were isolated from the infra-renal portion of the thoracic aorta as follows: the medial layer was separated from the intima and adventitial layers and cut into pieces approximately $1 \mathrm{~mm}^{2}$. The tissue was transferred into $25 \mathrm{~cm}^{2}$ tissue culture flasks pre-moistened with FCS and containing RPMI supplemented with antibiotics $(100 \mu \mathrm{g} / \mathrm{ml}$ streptomycin sulphate and $60 \mu \mathrm{g} / \mathrm{ml}$ benzylpenicillin), L-glutamine $(2 \mathrm{mM})$, and $10 \%$ FCS. The flasks were placed in an incubator at $37^{\circ} \mathrm{C}$ in a $5 \% \mathrm{CO}_{2}$ atmosphere and left undisturbed for $7 \mathrm{~d}$. After this the growth medium was changed twice weekly. Within 7-14 d, HVSMC grew out from the explants reaching confluence within 2 to 3 weeks and were harvested by conventional trypsinization and split for further culture into $75 \mathrm{~cm}^{2}$ tissue culture flasks.

HVSMC were cultured for $10 \mathrm{~d}$ in normal glucose (5 $\mathrm{mM}, \mathrm{NG})$, high glucose $(25 \mathrm{mM}, \mathrm{HG})$, and $\mathrm{NG}+$ L-buthionine-S, R-sulphoximine (10 $\mu \mathrm{M}, \mathrm{BSO})$. The medium was replaced twice weekly and all experiments were performed on cells up to and including the eighth passage. Alpha-lipoic acid $(25-100 \mu \mathrm{M})$ or L-cystine (1.5-2.5 mM) were added to the cells up to $48 \mathrm{~h}$ prior to extraction.
Harvesting of HVSMC for GSH and protein analysis

Confluent HVSMC monolayers were rinsed with PBS and scraped in ice-cold Hanks balanced salt solution (HBSS, Life Technologies). The cells were centrifuged at $225 \times \mathrm{g}$ at $4^{\circ} \mathrm{C}$ for $10 \mathrm{~min}$, the supernatant aspirated, and the resulting cell pellets stored at $-80^{\circ} \mathrm{C}$.

\section{Determination of intracellular glutathione (GSH)}

The cell pellets were thawed on ice and resuspended in $0.1 \%$ Triton X-100 in PBS (pH 7.4). Sonication was performed as previously described [16]. The samples were stabilized by the addition of $10 \%$ sulphosalicylic acid (SSA). After centrifugation at $13,000 \times g$ for $5 \mathrm{~min}$, the supernatant was analyzed for GSH according to the method described by Griffith [17], which has been automated on the Cobas Fara centrifugal analyzer.

\section{Protein determination}

Total protein was measured using a bicinchoninic acid (BCA) protein assay reagent kit (Pertio Science Ltd, Cheshire, UK). Bovine serum albumin (BSA) was used as a standard.

\section{Measurement of DNA damage}

The single-cell gel electrophoresis or comet assay is a microgel electrophoretic technique for the detection of DNA damage and repair in individual cells [18]. Frosted microscope slides were coated with $0.75 \%$ normal melting point agarose and allowed to set at $4^{\circ} \mathrm{C}$. Cells were trypsinized as described previously, centrifuged, and resuspended in $4 \mathrm{ml}$ of DMEM. An aliquot $(15 \mu \mathrm{l})$ of the cell suspension was mixed with $112 \mu$ l of $0.75 \%$ low melting point agarose and pipetted onto the frosted microscope slides, covered with a coverslip, and allowed to set at $4^{\circ} \mathrm{C}$ away from direct light. The slides were placed in lysis buffer $(2.5 \mathrm{mM} \mathrm{NaCl}, 100 \mathrm{mM}$ EDTA, $10 \mathrm{mM}$

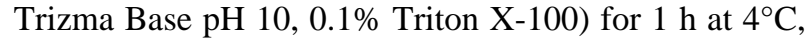
to allow disruption of the DNA base pairs, leaving only nuclear constituents intact. The slides were then placed in electrophoresis solution $(300 \mathrm{mM} \mathrm{NaOH}, 1 \mathrm{mM}$ EDTA) and the DNA allowed to unwind for $20 \mathrm{~min}$. The current was applied for exactly $20 \mathrm{~min}$ at $20 \mathrm{~V}$ and 300 $\mathrm{mA}$. During electrophoresis the cellular DNA migrates towards the anode, hence forming a comet "tail." After electrophoresis the slides were gently removed and the alkaline $\mathrm{pH}$ neutralized with $0.4 \mathrm{M}$ Tris $(\mathrm{pH} 7)$ for 20 min. Excess solution was removed before addition of ethidium bromide (50 $\mu \mathrm{l}$ of a $20 \mu \mathrm{g} / \mathrm{ml}$ solution [EtBr]) to each slide. A coverslip was placed onto each slide prior to storage at $4^{\circ} \mathrm{C}$. 


\section{Image analysis}

The slides were viewed using a fluorescence microscope and DNA damage quantified using the Komet 3.1 analysis package (Kinetic Imaging, UK). At least 50 cells for each condition were analyzed. The "comet" appears as a "head," which contains undamaged DNA, and a "tail," which contains damaged DNA. The level of DNA damage is directly proportional to length of the comet tail and intensity of the Et Br staining [19].

\section{Design of $\gamma$-GCS heavy and light subunit primers}

Primers were designed using published human glyceraldehyde 3-phosphate dehydrogenase (GAPDH, 20), $\gamma$-GCS heavy subunit (21), and $\gamma$-GCS light subunit (12) cDNA sequences. Gamma-glutamylcysteine synthetase light subunit $\left(\gamma-\mathrm{GCS}_{\mathrm{L}}\right)$ primers $\left(5^{\prime}\right.$-TGC CTC AAT GAC ACC ATT TAC-3', 5'-AAC CAA GTT AAT CTT GCC TCC-3'), $\gamma$-glutamylcysteine synthetase heavy subunit $\left(\gamma-\mathrm{GCS}_{\mathrm{H}}\right)$ primers $\left(5^{\prime}-\mathrm{AAC}\right.$ TCC CTC ATC CAT CTG G-3', 5'-AGA GAT GCT GTC TTG CAG G-3'), and GAPDH primers (5'- AGG GAC TCA TGA CCA CGG-3', 5' - TTG GAG GCC ATG TGG ACC-3') were synthesized.

\section{Extraction of total RNA and semiquantitative PCR}

Total RNA was extracted according to the method of Chomczynski and Sacchi [22]. RNA $(1 \mu \mathrm{g})$ was reverse transcribed using an oligo (dT) primer and Superscript RNase $\mathrm{H}^{-}$reverse transcriptase system (Life Technologies). An aliquot $(2 \mu \mathrm{l})$ of the subsequent cDNA was added directly to the PCR mastermix containing: 100 pmoles of sense and antisense primers, $200 \mu \mathrm{M}$ dNTP, 1.5 U Taq DNA polymerase, $10 \times$ PCR buffer $(200 \mathrm{mM}$ Tris- $\mathrm{HCl}$ (pH 8.4), $500 \mathrm{mM} \mathrm{KCl,} 2.5 \mathrm{mM} \mathrm{MgCl}_{2}$ ), and $10 \mu \mathrm{Ci}^{32} \mathrm{P}-\mathrm{dCTP}$ (NEN Life Sciences, Hounslow, UK, $370 \mathrm{MBq} / \mathrm{ml}$ ). During PCR, aliquots were withdrawn at regular intervals $(15,20,25,30,35,40$, or 45 cycles $)$ of amplification. An aliquot was electrophoresed in $1 \%$ agarose and radioactivity was determined on a Bio-Rad Molecular Imager system (Bio-Rad, Richmond, CA, USA). The exponential phase of the reaction was determined by plotting the amount of radioactivity from PCR products against the number of PCR cycles. Target mRNA was then coamplified with the internal control (GAPDH) using a Hybaid thermal cycler with the following cycling times and temperatures: 25 cycles of $94^{\circ}$ for $45 \mathrm{~s}, 55^{\circ}$ for $1 \mathrm{~min}$, and $72^{\circ}$ for $1 \mathrm{~min}$. The PCR reaction products were electrophoresed in a $1 \%$ agarose gel and fixed with $7 \%$ trichloroacetic acid. PCR products were quantified and normalized to GAPDH using a Bio-

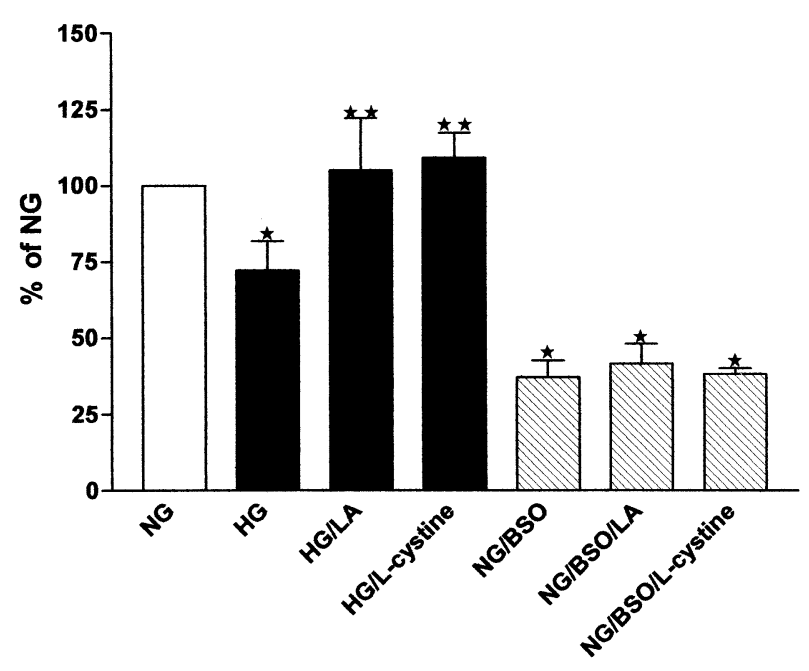

Fig. 1. Effects of glucose, BSO, $\alpha$-lipoic acid, and L-cystine on intracellular GSH levels in HVSMC. HVSMC were cultured in HG (25 $\mathrm{mM})$ and NG/BSO $(5 \mathrm{mM} / 10 \mu \mathrm{M})$ for $10 \mathrm{~d}$; $\alpha$-lipoic acid $(50 \mu \mathrm{M})$ and L-cystine $(2 \mathrm{mM})$ were added $24 \mathrm{~h}$ prior to intracellular GSH determination. Results are expressed as mean percentage \pm SEM $\left({ }^{*} p<.05\right.$ cf. NG, $n=6 ;{ }^{* *} p<.05$ cf. HG, $n=3$ ).

Rad Molecular Imager System GS-525 (Bio-Rad, Hertfordshire, UK) and Molecular Analyst Software.

\section{Statistical methods}

Statistical analysis was performed using Student's $t$-tests.

\section{RESULTS}

\section{Effects of glucose on intracellular GSH levels}

To investigate the effect of glucose on GSH levels in vascular smooth muscle cells, HVSMC were incubated with $5 \mathrm{mM}(\mathrm{NG})$ and $25 \mathrm{mM}(\mathrm{HG})$ glucose for $10 \mathrm{~d}$ prior to cellular GSH determination. GSH levels were significantly decreased in cells treated with high glucose; similarly, treatment of cells grown in NG with BSO (an inhibitor of $\gamma$-GCS) reduces GSH in HVSMC (Fig. 1).

\section{Effects of $\alpha$-lipoic acid and L-cystine on intracellular GSH levels}

To further investigate the mechanism by which GSH is depleted, $\alpha$-lipoic acid or L-cystine were added to HVSMC in order to restore GSH levels to normal. Preliminary experiments using a range of concentrations of both $\alpha$-lipoic acid (25-100 $\mu \mathrm{M})$ and L-cystine (1.5-2.5 $\mathrm{mM}$ ) were performed (data not shown), and the concentrations at which GSH levels were restored to normal were used in subsequent experiments. Addition of $\alpha$-lipoic acid $(50 \mu \mathrm{M})$, resulted in a significant elevation of 


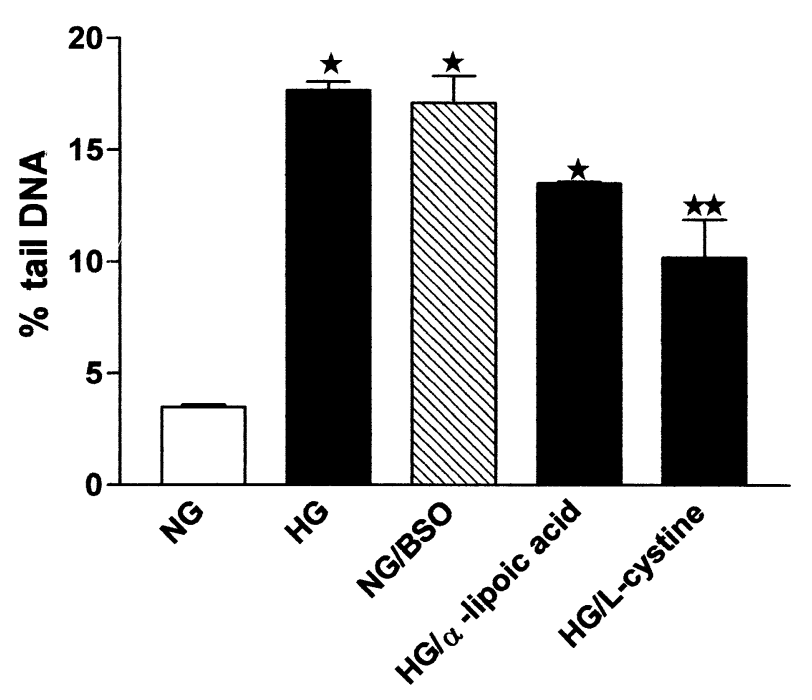

Fig. 2. Effects of glucose, BSO, $\alpha$-lipoic acid, and L-cystine on DNA damage in HVSMC. HVSMC were cultured in HG $(25 \mathrm{mM})$ and NG/BSO $(5 \mathrm{mM} / 10 \mu \mathrm{M})$ for a total of $10 \mathrm{~d} ; \alpha$-lipoic acid $(50 \mu \mathrm{M})$ and L-cystine $(2 \mathrm{mM})$ were added $24 \mathrm{~h}$ prior to assessment of DNA damage. Results are expressed as mean percentage of tail DNA \pm SEM $\left({ }^{*} p<.005\right.$ cf. NG, ${ }^{* *} p<.005$ cf. HG, $\left.n=3\right)$.

GSH levels in HG- but not in NG/BSO-treated HVSMC after $24 \mathrm{~h}$ (Fig 1). Alpha-lipoic acid (50-500 $\mu \mathrm{M})$ has been shown to substantially increase GSH levels in vitro [23] and in vivo [24] by improving cysteine utilization. For $\alpha$-lipoic acid to be effective, cells must possess functioning $\gamma$-GCS to cause an increase in GSH [23]. The addition of $\alpha$-lipoic acid did not significantly increase GSH levels in NG/BSO-treated cells indicating that inactivation of $\gamma$-GCS had occurred.

Likewise, addition of L-cystine (2 $\mathrm{mM}$ ) to cells grown in high glucose conditions but not in NG/BSO-treated cells resulted in a complete restoration of GSH levels after $24 \mathrm{~h}$ (Fig 1). L-cystine increases GSH in HVSMC treated with HG but does not significantly elevate GSH in BSO-treated cells; therefore, the mechanisms by which HG and BSO decrease GSH in HVSMC are different.

Effects of glucose, BSO, $\alpha$-lipoic acid, and L-cystine on DNA damage

GSH is an important antioxidant and the reduction in levels that occurs when HVSMC are exposed to high glucose conditions may be the primary event that predisposes the cells to oxidant-induced damage. To investigate the relationship between GSH levels and DNA damage, the comet assay was used, results of which are shown in Fig. 2. The amount of DNA damage as measured by the percentage comet tail, was significantly increased in HVSMC cultured in high glucose for $10 \mathrm{~d}$.
Table 1. Effects of HG, BSO, $\alpha$-Lipoic Acid, and L-Cystine on the mRNA Expression of Both Subunits of $\gamma$-GCS

\begin{tabular}{ccc}
\hline & $\gamma-\mathrm{GCS}_{\mathrm{L}}$ & $\gamma-\mathrm{GCS}_{\mathrm{H}}$ \\
\hline $\mathrm{NG}$ & 100 & 100 \\
$\mathrm{HG}$ & $69 \pm 4.1^{*}$ & $59 \pm 4.1^{*}$ \\
NG/BSO & $67 \pm 3.8^{*}$ & $56 \pm 5.5^{*}$ \\
$\mathrm{HG}+\alpha$-lipoic acid & $158.7 \pm 10.2^{* *}$ & $48 \pm 7.8^{*}$ \\
$\mathrm{HG}+$ L-cystine & $124.7 \pm 8.9^{* *}$ & $37 \pm 2.2^{*}$ \\
\hline
\end{tabular}

HVSMC were cultured in HG $(25 \mathrm{mM})$ and NG/BSO $(5 \mathrm{mM} / 10$ $\mu \mathrm{M})$ for a total of $10 \mathrm{~d}$; $\alpha$-lipoic acid $(50 \mu \mathrm{M})$ and L-cystine $(2 \mathrm{mM})$ were added $24 \mathrm{~h}$ prior to total RNA extraction.

Values are corrected for the housekeeping gene GAPDH and expressed as a mean percentage of NG \pm SEM of at least three independent experiments $\left(* p<.002 \mathrm{cf}\right.$. NG, ${ }^{* *} p<.002 \mathrm{cf}$. HG).

Likewise, the addition of BSO resulted in a significant increase in DNA damage of similar magnitude to that observed in HG conditions. When GSH levels were increased by the addition of $\alpha$-lipoic acid or L-cystine, the DNA damage was reduced (Fig. 2).

Effects of glucose, BSO, $\alpha$-lipoic acid, and L-cystine on the mRNA expression of $\gamma$-GCS heavy subunit

Gamma-GCS ${ }_{\mathrm{H}}$ subunit mRNA expression was determined by semiquantitative PCR using gene-specific primers to human $\gamma$-GCS ${ }_{\mathrm{H}}$ cDNA sequence. GAPDH, a constitutively expressed enzyme, served as an internal control. Values were corrected for GAPDH and expressed as a percentage of NG (Table 1). Incubation of HVSMC with $\mathrm{HG}$ and NG/BSO for $10 \mathrm{~d}$ caused a significant reduction in $\gamma-\mathrm{GCS}_{\mathrm{H}}$ subunit mRNA expression compared to NG. Gamma-GCS ${ }_{\mathrm{H}}$ mRNA expression was unaffected by treatment of HVSMC with $\alpha$-lipoic acid or L-cystine (Table 1).

Effects of glucose, BSO, $\alpha$-lipoic acid, and L-cystine on the mRNA expression of $\gamma$-GCS light subunit

As observed with the heavy subunit, incubation of HVSMC with HG and NG/BSO for $10 \mathrm{~d}$ caused a significant reduction in $\gamma-\mathrm{GCS}_{\mathrm{L}}$ subunit mRNA expression compared to NG (Table 1). However, in contrast to the heavy subunit, $\alpha$-lipoic acid and L-cystine significantly increased the mRNA expression of $\gamma-\mathrm{GCS}_{\mathrm{L}}$ in comparison to high glucose alone, with $\alpha$-lipoic acid causing the greatest increase (Table 1).

\section{DISCUSSION}

Oxidative stress occurred in HVSMC cultured in HG; this was evidenced by both a fall in GSH levels and an increase in DNA fragmentation. HVSMCs cultured in high glucose conditions for $10 \mathrm{~d}$ show a reduction of 
approximately $30 \%$ in intracellular GSH. A decrease in $\gamma$-GCS mRNA expression and increase in DNA damage accompany this reduction. The decrease observed is in agreement with published results; Yoshida et al. [15] found GSH levels 77\% of controls in erythrocytes from diabetic patients, Urata et al. [14] reported GSH levels $59 \%$ of normal glucose after $7 \mathrm{~d}$ in $22 \mathrm{mM}$ glucose, and Tachi et al. [25] found a decrease of $20 \%$ in HVSMC exposed to $27.5 \mathrm{mM}$ glucose for $10 \mathrm{~d}$. The depletion of GSH may be brought about through a variety of mechanisms, including an increased breakdown of GSH by $\gamma$-glutamyltranspeptidase, an increased export of GSSG from the cell, or a reduction in de novo synthesis through reduced activity of $\gamma$-GCS or availability of substrate. In human vascular smooth muscle cells, there is no significant difference in the rate of GSH efflux between cells exposed to high glucose compared to those in normal glucose [25]. The results from our study would suggest that in HVSMC the decrease is mediated by the availability of cyst(e)ine and gene expression of $\gamma$-GCS during HG conditions.

Treatment of the cells grown in HG with $\alpha$-lipoic acid $(50 \mu \mathrm{M})$ or L-cystine $(2 \mathrm{mM})$ for $24 \mathrm{~h}$ significantly increased GSH to near normal levels. By contrast, neither $\alpha$-lipoic acid nor L-cystine had any effect on GSH levels in HVSMC exposed to NG/BSO. Alpha-lipoic acid and L-cystine both increase the availability of cysteine intracellularly and require functional $\gamma$-GCS to restore GSH levels. Alpha-lipoic acid not only functions as an antioxidant but it is reduced to dihydrolipoate intracellularly; dihydrolipoate is released from the cell into the culture medium where it reduces extracellular cystine to cysteine. Cysteine is taken up by the cell via the $\mathrm{Na}^{+}$-dependent neutral amino acid transport system, ASC, thereby bypassing the cystine transport system $\mathrm{x}_{\mathrm{c}}{ }^{-}$, and results in GSH synthesis.

The supply of cyst(e)ine is rate limiting for synthesis of GSH in many cell types. In plasma and tissue culture media, cystine is the predominant form as cysteine is rapidly oxidized to cystine and may only be present in tissue culture medium for up to $30 \mathrm{~min}$, so there is a relatively short period for uptake to occur. Cystine transport is mediated by a $\mathrm{Na}^{+}$-independent anionic amino acid transport system $\mathrm{x}_{\mathrm{c}}{ }^{-}$, which exchanges cystine for intracellular glutamate [26] and is inhibited by glutamate. Intracellularly cystine is reduced to cysteine, which is utilized for GSH de novo synthesis. Inhibition of cystine influx has been shown to decrease intracellular GSH and conversely induction of cystine transport increases GSH content [27]; therefore, system $\mathrm{x}_{\mathrm{c}}{ }^{-}$is important in maintaining GSH levels in various cell types [28-31]. In human umbilical vein endothelial cells [32] and rat pancreatic acinar and islet cell lines [27], inhibition of GSH synthesis by BSO treatment, without alter- ing cystine transport, results in accumulation of cysteine within the cell. The fact that $\alpha$-lipoic acid and L-cystine significantly elevate GSH levels would lead to the assumption that in HG conditions unlike in NG/BSOtreated cells, there is no inactivation of $\gamma$-GCS in HVSMC and the availability of cyst(e)ine is rate-limiting. However it is possible that the restoration of GSH levels may be due to the additional effects of $\alpha$-lipoic acid and L-cystine on gene expression of the $\gamma$-GCS subunits.

Although much is known about the stimuli that increase or decrease $\gamma$-GCS, the detailed mechanism of regulation is not completely understood [33]. Several studies have demonstrated the presence of AP-1, AP-2, antioxidant response elements (ARE)/electrophile response elements (EpRE), and SP-1 binding sites in 5' region upstream of the transcription start site of the two subunits of $\gamma$-GCS [34,35]. The increased transcription of $\gamma$-GCS induced by agents such as xenobiotics is under the control of ARE/EpRE, which bind AP-1-like and NF-E2-like transcription factors [36]. AP-1 is known to be activated by high glucose conditions [37], but there are no studies to date examining the activity of NF-E2 transcription factors in cells exposed to high glucose. Gamma-GCS is a heterodimer composed of a catalytic heavy subunit that comprises all substrate binding sites and a light subunit that modulates the affinity of the heavy subunit for its substrates. Induction of $\gamma$-GCS expression by oxidative stress is well established [3840], however exposure to high-glucose conditions decreases mRNA expression of both subunits in HVSMC. Urata et al. [14] found that high concentrations of glucose in endothelial cells decreased GCS $_{\mathrm{H}}$ mRNA expression and inhibited the stimulatory effect of IL- $1 \beta$ and TNF- $\alpha$ on induction of $\gamma$-GCS. These results would suggest that glucose itself may have a direct effect on transcriptional regulation of both $\gamma$-GCS subunits, but further investigation is required.

The subunit genes are located on different chromosomes and mRNA levels and ratios of both subunits vary widely between different human tissues [12]. There are reported differences in response of $\gamma$-GCS between in vitro and in vivo systems, tissue types, and between the subunits themselves. This is evident in the response of the subunits in HVSMC to the addition of substances that

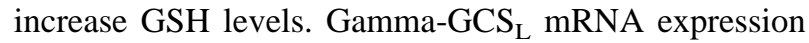
is upregulated by both $\alpha$-lipoic acid and L-cystine, whereas $\gamma-\mathrm{GCS}_{\mathrm{H}}$ mRNA expression is unaffected. This is in agreement with Han et al. [23], who observed that in human Jurkat cells, $\alpha$-lipoic acid $(100 \mu \mathrm{M}, 6-14 \mathrm{~h})$ increased GSH levels but did not affect $\gamma$-GCS ${ }_{\mathrm{H}}$ mRNA expression. Recently, Kwon and Stipanuk [41] have demonstrated that $\gamma-\mathrm{GCS}_{\mathrm{H}}$ is downregulated by cysteine in rat hepatocytes. They suggest that this regulation is 
independent of GSH levels as $\gamma$-GCS $\mathrm{GC}_{\mathrm{H}}$ mRNA expression was not closely associated with the concentration of GSH. The increase in $\gamma-\mathrm{GCS}_{\mathrm{L}}$ mRNA is translated into an increase in GSH levels even though there was no increase in $\gamma-\mathrm{GCS}_{\mathrm{H}}$. Tipnis et al. [42] found that overexpression of $\gamma$-GCS ${ }_{\mathrm{L}}$ in HeLa cells increased $\gamma$-GCS activity following GSH depletion by diethylmaleate. This increase in $\gamma$-GCS activity was accompanied by a restoration of GSH levels. While the heavy subunit possesses the catalytic activity and is subject to negative feedback inhibition by GSH, the kinetic properties are significantly influenced by light subunit binding [11]. The magnitude of the modulatory effect of $\gamma-\mathrm{GCS}_{\mathrm{L}}$ is species and cell dependent, but in all studies to date, the availability of the light subunit enhances the catalytic activity of $\gamma$ - $\mathrm{GCS}_{\mathrm{H}}[11,33,43]$. Gamma-GCS $\mathrm{L}_{\mathrm{L}}$ enhances the binding of $\gamma-\mathrm{GCS}_{\mathrm{H}}$ to its substrates, so the elevation in GSH may be as a result of increased association of the two subunits, thereby enabling more interaction with the increased cysteine made available through the conversion from cystine.

This is the first report of a reduction in mRNA of both heavy and light subunits of $\gamma$-GCS in HVSMC treated with $\mathrm{HG}$ or NG/BSO for $10 \mathrm{~d}$. Previous studies have reported increases in mRNA of both subunits on incubation with BSO; Tian [44] found that exposure to BSO $(100 \mu \mathrm{M}$ for $12 \mathrm{~h})$ caused increases in the steady state mRNA levels of both subunits in rat lung epithelial L2 cells. Similarly, Cai [45] observed activation of both subunits in rat hepatocytes treated with 0.1-5 mM BSO for $12 \mathrm{~h}$. In our study, the BSO concentration was 10fold lower and exposure was $10 \mathrm{~d}$ rather than $12 \mathrm{~h}$. Vascular complications of diabetes are associated with long-term hyperglycemia-induced oxidative stress; therefore, a $10 \mathrm{~d}$ experimental period was used. It has been suggested that there is a threshold value below which the level of GSH must fall before activation of $\gamma$-GCS occurs [33]. This may explain the reason for not observing any upregulation of the $\gamma$-GCS subunits in BSO-treated HVSMC.

The decrease in GSH may be the primary event that predisposes the cells to oxidant-induced damage. When GSH levels are reduced in HVSMC by incubation with glucose or BSO, the amount of DNA damage is significantly increased. Treatment of the cells with $\alpha$-lipoic acid and L-cystine, which result in the elevation of GSH levels, subsequently decrease DNA damage. In view of the association between GSH levels and amount of DNA damage, and the fact that vascular disease is responsible for most of the long-term complications of diabetes mellitus, maintenance of GSH levels in diabetic patients may prove beneficial. This may be most effectively achieved by increasing the availability of cyst(e)ine in combination with increasing the activity of $\gamma$-GCS. Gene transfer techniques have been used to increase GSH levels through increasing activity of $\gamma$-GCS. Mulcahy et al. [40] successfully transfected complementary DNAs for the heavy and light subunits of human $\gamma$-GCS into COS-7 cells resulting in an elevation of intracellular glutathione.

In conclusion, we have demonstrated that hyperglycemia-induced oxidative stress occurs in HVSMC as evidenced by a decrease in GSH levels and an increase in DNA damage. The change in GSH is accompanied by a decrease in the mRNA expression of both $\gamma$-GCS subunits. The mechanisms by which HG and BSO reduce GSH are different; BSO inactivates $\gamma$-GCS whereas the amount of cyst(e)ine is rate-limiting in HG conditions. Addition of $\alpha$-lipoic acid and L-cystine to HG-treated HVSMC, which increase the availability of cysteine, results in an elevation of intracellular GSH levels, upregulation of $\gamma-\mathrm{GCS}_{\mathrm{L}}$ mRNA expression, and reduction in DNA damage after $24 \mathrm{~h}$. The mechanisms responsible for the regulation of the $\gamma$-GCS subunits are as yet unknown and require further investigation, but, it is evident that they are differentially regulated by high glucose in HVSMC. The study of these regulatory mechanisms is critical in the understanding of the processes involved in hyperglycemia-induced oxidative stress, which contributes to the vascular complications of diabetes. Modulation of intracellular GSH levels through pharmacological means or regulation of $\gamma$-GCS may inhibit the hyperglycemia-induced oxidative response in diabetes.

\section{REFERENCES}

[1] Seltzer, H. S. Blood glutathione in mild diabetes before treatment and during sulphonylurea-induced hypoglycemia. Proc. Soc. Exp. Biol. Med. 95:74-76; 1957.

[2] Awadalla, R.; El-Dessoukey, E. A.; Doss, H.; Klalifa, K. Bloodreduced glutathione, serum ceruloplasmin and mineral changes in juvenile diabetes. Z. Ernahrungswiss 17:72-78; 1978.

[3] Chari, S. W.; Nath, N.; Rathi, A. B. Glutathione and its redox system in diabetic polymorphonuclear leukocytes. Am. J. Med. Sci. 287:14-15; 1984.

[4] Thomas, G.; Skrinska, V.; Lucas, F. V.; Schumacher, O. P. Platelet glutathione and thromboxane synthesis in diabetes. Diabetes 34:951-954; 1985.

[5] Tagami, S.; Kondo, T.; Yoshida, K.; Hirokawa, J.; Ohtsuka, Y.; Kawakami, Y. Effect of insulin on impaired antioxidant activities in aortic endothelial cells from diabetic rabbits. Metabolism 41: 1053-1058; 1992.

[6] Sen, C. K.; Packer, L. Antioxidant and redox regulation of gene transcription. FASEB J. 10:709-720; 1996.

[7] Ginn-Pease, M. E.; Whisler, R. L. Optimal NF- $\kappa$ B-mediated transcriptional responses in Jurkat cells exposed to oxidative stress are dependent on intracellular glutathione and costimulatory signals. Biochem. Biophys. Res. Commun. 226:695-706; 1996.

[8] Arrigo, A. P. Gene expression and the thiol redox state. Free Radic. Biol. Med. 27:936-944; 1999.

[9] Richman, P. G.; Meister, A. Regulation of $\gamma$-glutamylcysteine synthetase by nonallosteric feedback inhibition by glutathione. J. Biol. Chem. 250:1422-1426; 1975. 
[10] Seelig, G. F.; Simondsen, R. P.; Meister, A. Reversible dissociation of $\gamma$-GCS into two subunits. J. Biol. Chem. 259:9345-9347; 1984.

[11] Huang, C. S.; Anderson, M. E.; Meister, A. Amino acid sequence and function of the light subunit of rat kidney $\gamma$-GCS. J. Biol. Chem. 268:20578-20583; 1993.

[12] Gipp, J. J.; Bailey, H. H.; Mulcahy, R. T. Cloning and sequencing of the cDNA for the light subunit of human liver $\gamma$-glutamylcysteine synthetase and relative mRNA levels for heavy and light subunits in human normal tissues. Biochem. Biophys. Res. Commun. 206:584-589; 1995 .

[13] Murakami, K.; Kondo, T.; Ohtsuka, Y.; Fujiwara, Y.; Shimada, M.; Kawakami, Y. Impairment of glutathione metabolism in erythrocytes from patients with diabetes mellitus. Metabolism 38:753-758; 1989.

[14] Urata, Y.; Yamamoto, H.; Goto, S.; Tsushima, H.; Akazawa, S.; Yamashita, S.; Nagataki, S.; Kondo, T. Long exposure to high glucose concentration impairs the responsive expression of $\gamma$-GCS by interleukin- $1 \beta$ and tumor necrosis factor- $\alpha$ in mouse endothethial cells. J. Biol. Chem. 271:15146-15152; 1996.

[15] Yosida, K.; Hirokawa, J.; Tagami, S.; Kawakami, Y.; Urata, Y.; Kondo, T. Weakened cellular scavenging activity against oxidative stress in diabetes mellitus: regulation of glutathione synthesis and efflux. Diabetologia 38:201-210; 1995.

[16] Sharpe, P. C.; Yue, K. K. M.; Catherwood, M. A.; McMaster, D.; Trimble, E. R. The effects of glucose-induced oxidative stress on growth and extracellular matrix gene expression of vascular smooth muscle cells. Diabetologia 41:1210-1219; 1998.

[17] Griffith, O. W. Determination of glutathione and glutathione disulfide using glutathione reductase and 2-vinylpyridine. Analyt. Biochem. 106:207-212; 1980.

[18] Singh, N. P.; McCoy, M. T.; Tice, R. R.; Schnider, E. L. A simple technique for quantification of low levels of DNA damage in individual cells. Expt. Cell Res. 175:184-191; 1988.

[19] Green, M. H. L.; Lowe, J. E.; Delaney, C. A.; Green, I. C. Comet assay to detect nitric oxide dependent DNA damage in mammalian cells. Methods Enzymol. 269:243-266; 1996.

[20] Sabath, D. E.; Broome, H. E.; Prystowsky, M. B. Glyceraldehyde3-phosphate dehydrogenase mRNA is a major interleukin-2-induced transcript in a cloned T-helper lymphocyte. Gene 91:185191; 1990

[21] Gipp, J. J.; Chang, C.; Mulcahy, R. T. Cloning and nucleotide sequence of a full-length cDNA for human liver $\gamma$-glutamylcysteine synthetase. Biochem. Biophys. Res. Commun. 185:29-35; 1992.

[22] Chomczynski, P.; Sacchi, N. Single-step method of RNA isolation by acid guanidinium thiocyanate phenol-chloroform extraction. Anal. Biochem. 162:156-159; 1987.

[23] Han, D.; Handelman, G.; Marcocci, L.; Sen, C. K.; Roy, S.; Kobuchi, H.; Tritschler, H. J.; Flohe, L.; Packer, L. Lipoic acid increases de novo synthesis of cellular glutathione by improving cystine utilization. BioFactors 6:321-338; 1997.

[24] Busse, E.; Zimmer, G.; Schopohl, B.; Kornhuber, B. Influence of $\alpha$-lipoic acid on intracellular glutathione in vitro and in vivo. Arzneimittel-Forschung Drug Res. 42:829-831; 1992.

[25] Tachi, Y.; Okuda, Y.; Bannai, C.; Okamura, N.; Bannai, S.; Yamashita, K. High concentration of glucose causes impairment of the function of glutathione redox cycle in human vascular smooth muscle cells. FEBS Lett. 42:19-22; 1998.

[26] Bannai, S.; Tateishi, N. Role of membrane transport in metabolism and function of glutathione in mammals. J. Membrane Biol. 89:1-8; 1986.

[27] Sato, H.; Kuriyama-Matsumura, K.; Siow, R. C. M.; Ishii, T.; Bannai, S.; Mann, G. E. Induction of cystine transport via system $\mathrm{x}_{\mathrm{c}}{ }^{-}$and maintenance of intracellular glutathione levels in pancreatic acinar and islet cell lines. Biochim. Biophys. Acta 1414:8594; 1998.

[28] Deneke, S. M.; Baxter, D. F.; Phelps, D. T.; Fanburg, B. L.
Increase in endothelial cell glutathione and precursor amino acid uptake by diethyl maleate and hyperoxia. Am. J. Physiol. 257: L265-L271; 1989.

[29] Miura, K.; Ishii, I.; Sugita, Y.; Bannai, S. Cystine uptake and glutathione levels in endothelial cells exposed to oxidative stress. Am. J. Physiol. 262:C50-C58; 1992.

[30] Watanabe, H.; Bannai, S. Induction of cystine transport activity in mouse peritoneal macrophages. J. Exp. Med. 165:628-640; 1987.

[31] Sagara, J.; Miura, K.; Bannai, S. Maintenance of neuronal glutathione by glial cells. J. Neurochem. 6:1672-1676; 1993.

[32] Cotgreave, I. A.; Schuppe-Koistinen, I. A role for $\gamma$-glutamylpeptidase in the transport of cystine into human endothelial cells: relationship to intracellular glutathione. Biochim. Biophys. Acta 1222:375-382; 1994.

[33] Griffith, O. W. Biologic and pharmacologic regulation of mammalian glutathione synthesis. Free Radic. Biol. Med. 27:922-935; 1999.

[34] Mulcahy, T. R.; Wartman, M. A.; Bailey, H. H.; Gipp, J. J. Constitutive and $\beta$-naphthoflavone-induced expression of the human $\gamma$-glutamylcysteine synthetase heavy subunit gene is regulated by a distal antioxidant response element/TRE sequence. J. Biol. Chem. 272:7445-7454; 1997.

[35] Rahman, I.; Bel, A.; Mulier, B.; Lawson, M. F.; Harrison, D. J.; MacNee, W.; Smith, C. A. D. Regulation of redox glutathione levels and gene transcription in lung inflammation: therapeutic approaches. Biochem. Biophys. Res. Commun. 229:832-837; 1996.

[36] Wild, A. C.; Moinova, H. R.; Mulcahy, R. T. Regulation of $\gamma$-glutamylcysteine synthetase subunit gene expression by the transcription factor Nrf2. J. Biol. Chem. 274:33627-33636; 1999.

[37] Kreisberg, J. L.; Radnik, R. A.; Ayo, S. H.; Garoni, J.; Saikumar, P. High glucose elevates c-fos and c-jun transcripts and proteins in mesangial cell cultures. Kidney Int. 46:105-112; 1994.

[38] Duan, D.; Bukpitt, A. R.; Pinkerton, K. E.; Ji, C.; Ploppoer, G. G. Ozone-induced alterations in glutathione in lung subcompartments of rats and monkeys. Am. J. Respir. Cell Mol. Biol. 14: $70-75 ; 1996$.

[39] Liu, R. M.; Gao, L.; Choi, J.; Forman, H. J. Gamma-glutamylcysteine synthetase: mRNA stabilization and independent subunit transcription by 4-hydroxy-2-nonenal. Am. J. Physiol. 275:L861L869; 1998.

[40] Pietarinen-Runtti, P.; Raivio, K. O.; Saksela, M.; Asikainen, T. M.; Kinnula, V. L. Antioxidant enzyme regulation and resistance to oxidants of human bronchial epithelial cells cultured under hypoxic conditions. Am. Respir. Cell Mol. Biol. 19:286292; 1998

[41] Hye Kwon, Y.; Stipanuk, M. H. Cysteine regulates expression of cysteine dioxygenase and $\gamma$-glutamylcysteine synthetase in cultured rat hepatocytes. Amer. J. Physiol. Endocrinol. Metab. 280: E804-E815; 2001.

[42] Tipnis, S. R.; Blake, D. G.; Shepherd, A. G.; McLellan, L. I. Overexpression of the regulatory subunit of $\gamma$-glutamylcysteine synthetase in HeLa cells increases glutamylcysteine synthetase activity and confers drug resistance. Biochem. J. 337:559-565; 1999.

[43] Mulcahy, R. T.; Bailey, H. H.; Gipp, J. J. Transfection of complementary DNAs for heavy and light subunits of human $\gamma$-glutamylcysteine synthetase results in an elevation of intracellular glutathione and resistance to melphalan. Cancer Res. 55:47714775; 1995.

[44] Tian, L.; Shi, M. M.; Forman, H. J. Increased transcription of the regulatory subunit of $\gamma$-glutamylcysteine synthetase in rat lung epithelial L2 cells exposed to oxidative stress or glutathione depletion. Arch. Biochem. Biophys. 342:126-133; 1997.

[45] Cai, J.; Sun, W.; Lu, S. C. Differential regulation of $\gamma$-glutamylcysteine synthetase heavy and light subunit gene expression. Biochem. J. 326:167-172; 1997. 